\title{
Immunopurification of heterogeneous nuclear ribonucleoprotein particles reveals an assortment of RNA-binding proteins
}

\author{
Serafín Piñol-Roma, Yang Do Choi, ${ }^{1}$ Michael J. Matunis, and Gideon Dreyfuss \\ Department of Biochemistry, Molecular Biology and Cell Biology, Northwestern University, Evanston, Illinois 60208 USA
}

\begin{abstract}
Heterogeneous nuclear RNA-ribonucleoprotein (hnRNP) particles can be efficiently purifed by a specific, rapid, and mild procedure using monoclonal antibodies to hnRNP proteins. We report here on the detailed analysis of the protein composition of immunopurified hnRNP particles from human HeLa cells. By two-dimensional gel electrophoresis, immunopurified hnRNP particles contain at least 24 polypeptides in the range of $34,000-120,000$ daltons. The abundant $30,000-40,000$ dalton proteins, A, B, and C, described previously, are a subset of these polypeptides. The protein compositions of hnRNP particles found in the nucleoplasm fraction and in the chromatin-nucleolar fraction are very similar. Upon addition of the polyanion heparin, most of the major proteins remain associated in heparin-resistant particles, and only several, mostly minor, proteins dissociate. This provides an aid in the classification of the proteins and an additional criterion for the definition of hnRNP particle components. Chromatography on single-stranded DNA (ssDNA)-agarose in a heparin- and moderate or high salt (higher than $300 \mathrm{~mm} \mathrm{NaCl}$ )-resistant manner suggests that most, if not all, of these proteins are single-stranded nucleic acid-binding proteins. We describe a general method for the large-scale purification of hnRNP proteins by affinity chromatography on ssDNA columns and its use for the production of new monoclonal antibodies to hnRNP proteins.
\end{abstract}

[Key Words: Ribonucleoprotein particles; RNA packaging; nuclear proteins; monoclonal antibodies; affinity chromatography]

Received September 30, 1987; revised version accepted December 31, 1987.

Heterogeneous nuclear RNAs (hnRNAs) are found in the cell in association with specific proteins to form hnRNA-ribonucleoprotein (hnRNP) complexes, also referred to as hnRNP particles (reviewed in Dreyfuss 1986). The hnRNAs packaged within these hnRNP complexes are believed to constitute the native substrates for the processing events that lead to formation of mature mRNA. Evidence for the association of hnRNA with proteins comes from electron microscopy studies in which protein particles are seen on nascent transcripts in spread chromatin preparations (Miller and Bakken 1972; Foe et al. 1976; Laird et al. 1976; McKnight and Miller 1976; Beyer et al. 1980; Osheim et al. 1985), from sedimentation of rapidly labeled hnRNA with proteins on sucrose gradients (Samarina et al. 1968; Martin et al. 1974, 1978; Pederson 1974; Beyer et al. 1977; Karn et al. 1977; Stevenin et al. 1977; Maundrell and Scherrer 1979; Walker et al. 1980; Jacob et al. 1981; Steitz and Kamen 1981; Lothstein et al. 1985; Wilk et al. 1985|, and from photochemical cross-linking in intact cells (Mayrand et al. 1981; van Eekelen and van Venrooij

1Present address: Department of Agricultural Chemistry, Seoul National University, Suwon, Korea 170.
1981; van Eekelen et al. 1981; Economides and Pederson 1983; Dreyfuss et al. 1984b). hnRNA released from nuclei by mechanical disruption or by limited RNase digestion sediments as heterodisperse material between $30 S$ and $250 S$ and upon mild RNase treatment is converted to a form that sediments at $30 \mathrm{~S}-40 \mathrm{~S}$ (30S particles). This observation, together with the appearance of hnRNPs by electron microscopy, suggested a beads-ona-string arrangement for the $30 \mathrm{~S}$ protein particles /'monoparticles') on the hnRNA strand.

One of the major questions in the study of hnRNP complexes centers around their protein composition. The protein composition of intact hnRNP particles has not been possible to determine directly (without digestion with nuclease to generate $30 \mathrm{~S}$ particles) because too many other cellular particles co-sediment with them in the gradients. Analysis of $30 \mathrm{~S}$ monoparticles revealed, in addition to the fragments of hnRNA, a set of proteins whose reported number varies from 6 to well over 20. Of these, a major sextet of proteins in the $30,000-$ to 45,000 -dalton range (the $A, B$, and $C$ group proteins) as visualized by one-dimensional sodium dodecyl sulfatepolyacrylamide gel electrophoresis (SDS-PAGE) is consistently detected, and these six proteins have often 
been referred to as the hnRNP 'core' proteins (Beyer et al. 1977; LeStourgeon et al. 1981; Chung and Wooley 1986). Additional proteins of higher molecular weight were also detected in the $30 \mathrm{~S}$ fraction, and more detailed analysis by two-dimensional gel electrophoresis (Wilk et al. 1985) revealed a greater complexity even in the A, B, and $C$ protein molecular-weight range. However, unambiguous assignment of the additional (non- $A$, non- $B$, non-C) proteins was not possible based on sedimentation studies alone. The difficulties stem from the intrinsic limitations of the sedimentation method. The authenticity of hnRNP proteins obtained by this fractionation procedure is subject to uncertainties because of the absence of assays that could distinguish specific hnRNA-binding proteins from those that may become adventitiously associated with the hnRNA during the isolation procedure or that may be part of other structures that cosediment with hnRNP particles on sucrose gradients; because of the incomplete purification that it affords; and because of possible loss of proteins that could occur during the lengthy procedure due to proteolysis or nucleases.

A more stringent definition of genuine hnRNP proteins has been provided by UV light-induced covalent cross-linking of proteins to RNA in vivo, which allows identification of proteins that are bound to the RNA in the cell (Mayrand et al. 1981; Dreyfuss et al. 1984a,b). These studies showed numerous proteins, including those that correspond in SDS-PAGE mobility to A, B, and $C$ proteins, but the proteins are no longer useful for biochemical studies. Nevertheless, because of the specificity of this method, we have used UV cross-linked hnRNPs as a source of genuine hnRNP proteins for immunization of mice to produce monoclonal antibodies to these proteins (Choi and Dreyfuss 1984b; Dreyfuss et al. 1984b), thus providing highly specific probes for the study of individual hnRNP proteins and of intact hnRNP particles. This was especially apparent by the ability of monoclonal antibodies against different genuine hnRNP proteins to immunopurify specific hnRNAcontaining complexes consisting of virtually identical sets of proteins (Choi and Dreyfuss 1984a). The specificity of the immunopurification procedure can thus be taken advantage of for the identification of the components of intact hnRNP particles and for the study of their structure and function. The antibodies have also been useful reagents to investigate the role of hnRNP proteins in mRNA splicing (Choi et al. 1986; Sierakowska et al. 1986).

In the work described here, we have analyzed the composition of hnRNP complexes obtained by immunopurification from HeLa cells with monoclonal antibodies. We identify a set of over 24 proteins by two-dimensional gel electrophoresis as consistent hnRNP components. In addition to the proteins previously assigned to $30 \mathrm{~S}$ hnRNP particles (Wilk et al. 1985), immunopurification of intact hnRNP particles reveals the presence of several major proteins of molecular weights greater than 45,000 daltons. Most of the proteins remain associated in heparin-resistant complexes, a finding that reaffirms their authenticity as components of hnRNP particles. Furthermore, we found that most of the hnRNP proteins bind to single-stranded DNA (ssDNA) in a heparin-resistant manner and require considerable salt concentrations for dissociation from the ssDNA. We describe a method for the separation and large-scale purification of hnRNP proteins by chromatography on ssDNA-agarose and their use for the production of specific monoclonal antibody probes.

\section{Results \\ Immunopurification of hnRNP complexes}

hnRNP complexes can be isolated from vertebrate nucleoplasm by a rapid, specific, and efficient immunopurification procedure using monoclonal antibodies to hnRNP proteins (Choi and Dreyfuss 1984a). Previously, we have shown that monoclonal antibodies to the hnRNP C proteins (2B12 and 4F4) and to the hnRNP $120 \mathrm{~K}$ ( $\mathrm{K}=$ kilodalton) protein (3G6) purify a similar set of hnRNP proteins (Choi and Dreyfuss 1984a). We have now produced monoclonal antibodies against at least seven different hnRNP proteins and used them to immunopurify hnRNP particles, and the results are all virtually identical. For example, as shown in Figure 1, a new monoclonal antibody, 4B10, to the Al hnRNP protein also isolates hnRNP complexes of similar composition to those isolated with 4F4 (Fig. 1, lanes 4B10-T and 4F4-T). The major proteins are indicated as doublets designated A, B, and C, after nomenclature of Beyer and coworkers (1977), 68K and 120K, and numerous additional proteins are also detected. The effectiveness of the procedure is apparent by the essentially complete absence of abundant nuclear proteins such as histones. The specificity of 4B10 for Al was shown by immunoprecipitation carried out in the presence of the ionic detergent Empigen BB (Fig. 1, lane 4B10-E), which solubilizes cellular structures and disaggregates proteins while still permitting efficient antibody-antigen interaction /Choi and Dreyfuss 1984b). Control immunoprecipitations were carried out with identical amounts of mouse nonspecific immunoglobulins obtained from ascites fluid of mice inoculated with the parent myeloma line SP2/0. The monoclonal antibody $4 \mathrm{~B} 10$ recognizes only $\mathrm{A} 1$ and not A2 or the B proteins, in contrast to the monoclonal antibodies described by Leser and co-workers (1984) and antibodies against the Al-related UP1 /Valentini et al. 1985). A comparison of lanes 4B10-T and 4F4-T reveals some minor quantitative differences. The relative intensity of the bands of the $\mathrm{C}$ proteins to that of the A2 protein band in immunopurified hnRNP complexes is the same for all of the different antibodies used so far, suggesting that there are probably no free (not part of the hnRNP complex) $C$ proteins in the nucleoplasm. This observation is consistent with sucrose gradient sedimentation experiments of total nucleoplasm in which no free $\mathrm{C}$ proteins were detected at the top of the gradient by immunoblotting (Y.D. Choi and G. Dreyfuss, un- 


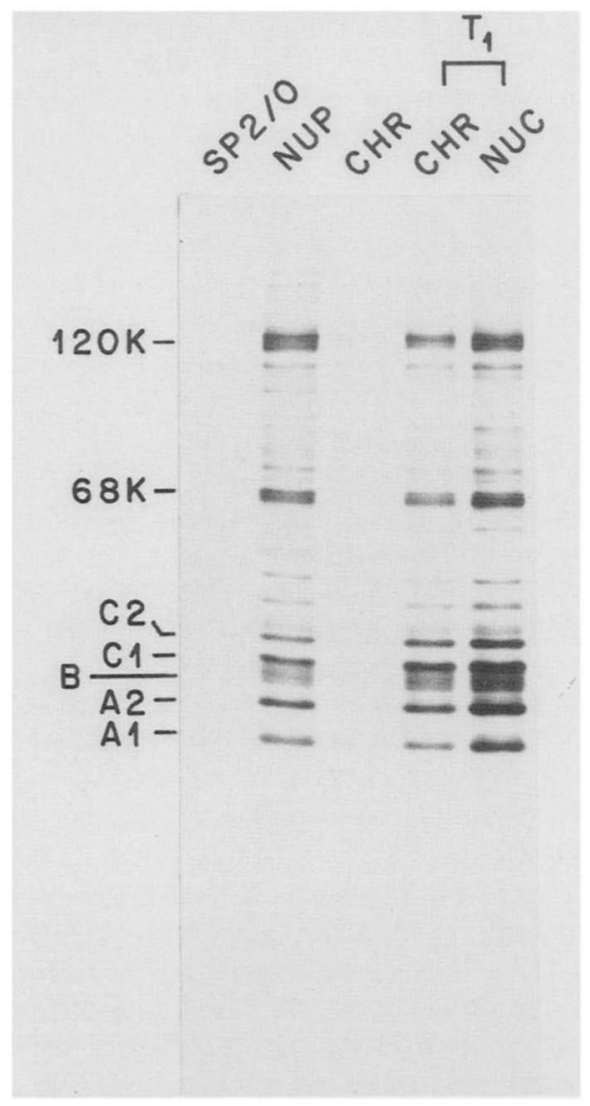

Figure 1. Immunopurification of hnRNP particles with monoclonal antibodies against the Al hnRNP protein (4B10) or the hnRNP C proteins (4F4). The hnRNP particles were immunopurified from nucleoplasm of $\left[{ }^{35} S\right]$ methionine-labeled HeLa cells in the presence of the nonionic detergent Triton X-100 at $0.5 \%$ (lanes T). Antigen specificity of the antibodies was demonstrated by immunoprecipitation in the presence of the ionic detergent Empigen BB at 1\% (lanes $E$ ). Control immunoprecipitations were carried out with ascites fluid of BALB/c mouse inoculated intraperitoneally with the parent myeloma line SP2/0. Molecular weights of the standard proteins are indicated on the right.

publ.). In contrast, the relative amount of $\mathrm{Al}$ in complexes isolated with 4B10 at $100 \mathrm{~mm} \mathrm{NaCl}$ (lane 4B10-T) was higher by up to $40 \%$ compared to complexes isolated with the anti-C protein antibody 4F4 (lane 4F4-T). This suggests that under these conditions, $\mathrm{Al}$ is overrepresented, probably because there is some free $\mathrm{Al}$ that was immunoprecipitated directly by $4 \mathrm{~B} 10$. The relative amount of $\mathrm{Al}$ in complexes purified with $4 \mathrm{~F} 4$ at $100 \mathrm{mM}$ $\mathrm{NaCl}$ was lower than that at $50 \mathrm{~mm}$, indicating that the association of Al with the hnRNP complex is very sensitive to salt concentration (data not shown). It is therefore difficult to estimate the precise stoichiometry of $\mathrm{Al}$ in hnRNP particles in vivo. The immunoprecipitation experiments suggest that all of the major hnRNP proteins for which such isolations have been attempted so far, including $\mathrm{Al}, \mathrm{Cl}, \mathrm{C} 2$ and $120 \mathrm{~K}$, are accessible to antibodies in hnRNP complexes.

\section{Similarity of nucleoplasmic hnRNP complexes to hnRNP complexes in the chromatin-nucleolar fraction}

Large hnRNP complexes are usually isolated from the nucleoplasm after nuclear fractionation (Pederson 1974). The nucleoplasm is operationally defined as the supernatant that is obtained after low-speed centrifugation of sonicated nuclei, and the pellet is the fraction that contains chromatin and nucleoli. About half of the hnRNA and hnRNP proteins (such as $\mathrm{Al}, \mathrm{Cl}, \mathrm{C} 2$, and $120 \mathrm{~K}$ ) are found with the chromatin-nucleoli fraction after such nuclear fractionation. To study the composition of hnRNP complexes in the fraction containing the chromatin and nucleoli, the low-speed pellet was digested with RNase $\mathrm{Tl}$ and the released hnRNP proteins were examined after immunoprecipitation with 4F4. The protein composition of the hnRNP complexes in the chromatin-nucleoli fraction (Fig. 2, lane CHR-T1) was found to be virtually identical to that of hnRNP complexes in nucleoplasm (lane NUP). This suggests that there is only one predominant type of $\mathrm{C}$ protein-containing hnRNP complex in the cell. Similar results were also obtained

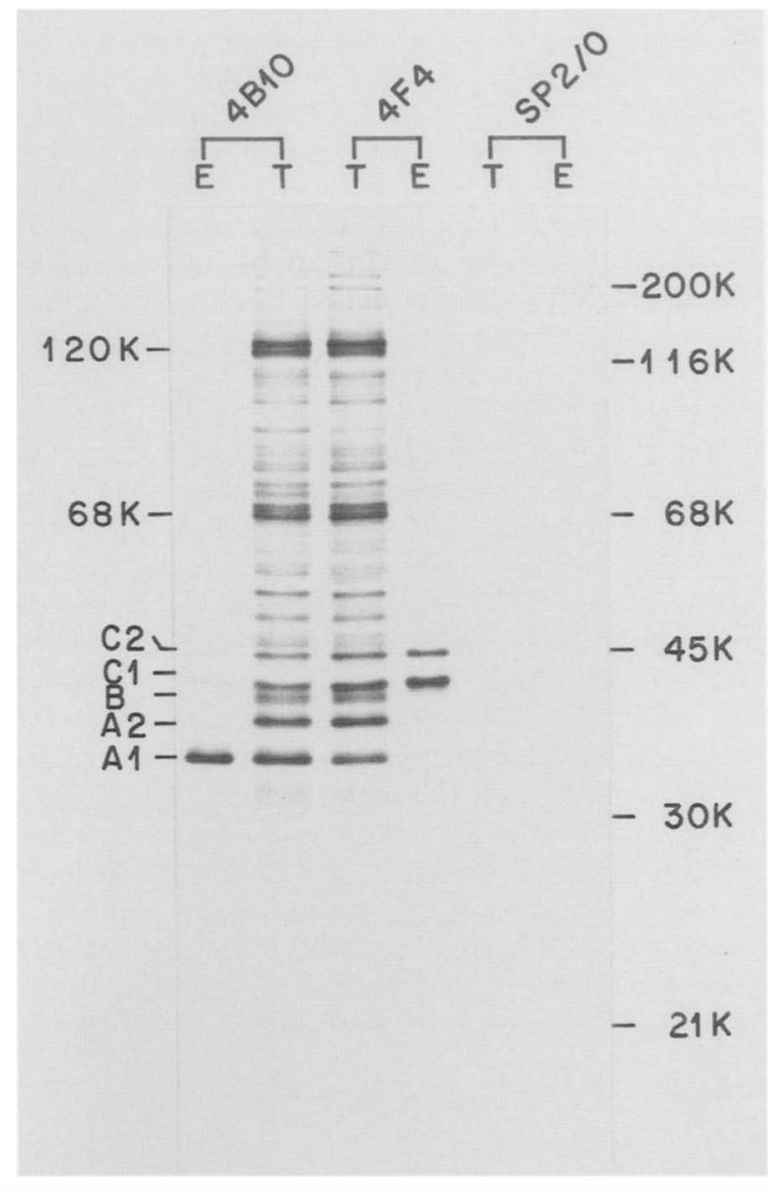

Figure 2. Recovery of the hnRNP complex from chromatinassociated fraction. hnRNP complexes were immunopurified with monoclonal antibody 4F4 from nucleoplasm (lane NUP) or from chromatin-associated fraction released by RNase digestion (lane CHR-T1). Control extraction without RNase Tl digestion (lane $C H R$ ) or control digestion of sonicated nuclear fraction (lane NUC-T1) were included for comparison. 
using micrococcal nuclease instead of RNase T1 (data not shown). The same amount of hnRNP complexes was recovered by digestion of total (unfractionated) nuclei with RNase T1 (lane NUC-T1), as in the combined nucleoplasm and T1-digested CHR fraction. Without exogenous ribonuclease digestion, little hnRNP protein was released from the chromatin-containing fraction (lane CHR). The mode of association of the hnRNP complexes with the chromatin fraction is not known, but it is clearly an RNase-sensitive linkage. It probably includes mostly chromatin-associated nascent transcripts and possibly complete transcripts that may be associated with large insoluble structures, such as the putative nuclear matrix.

\section{High-molecular-weight proteins are abundant components of hnRNP complexes}

The proteins of hnRNP complexes purified with 4F4 from HeLa nucleoplasm were analyzed by two-dimensional nonequilibrium $\mathrm{pH}$ gradient polyacrylamide gel electrophoresis (NEPHGE) (Fig. 3). The pattern is quite complex; the region between 30,000 and 45,000 daltons resolves into a much larger array of proteins than suggested by one-dimensional SDS-PAGE analysis, in agreement with the results of Wilk and co-workers (1985). In addition, numerous higher-molecular-weight proteins are present. Some of the observed complexity may be accounted for by post-transcriptional modifications of several of the proteins. For example, it has been shown previously that the group A and B proteins contain the unusual amino acid derivative dimethylarginine
(Beyer et al. 1977; Karn et al. 1977) and that the C proteins and the $120 \mathrm{~K}$ protein are highly phosphorylated (Choi and Dreyfuss 1984b; Holcomb and Friedman 1984). But it is apparent that there are additional proteins in the complex that have not been previously characterized and that are, as will be discussed below, immunologically distinct and are not the result of modifications of known hnRNP proteins.

To obtain sensitive detection and, at the same time, ascertain that the relative abundance of the proteins is not biased by the methionine content, the proteins of hnRNP particles isolated with 4F4 from cells labeled overnight with either $\left[{ }^{35} \mathrm{~S}\right]$ methionine or ${ }^{3} \mathrm{H}$-labeled amino acids were analyzed side by side (Fig. 3). In general, there is good correspondence between the labeling with $\left[{ }^{35} \mathrm{~S}\right]$ methionine and with the ${ }^{3} \mathrm{H}$-labeled amino acid mixture. The $\left[{ }^{35} \mathrm{~S}\right]$ methionine is more convenient to use and of higher specific radioactivity and was therefore used in subsequent experiments. To facilitate further discussion, we have designated the observed polypeptides alphabetically following the A, B, C designation of Beyer et al. (1977) and, to the extent possible, also that of Wilk et al. (1985). The proteins larger than the D proteins have not been named previously because their authenticity could not be ascertained, although many of them can, in retrospect, be seen in previously published analyses of the $30 \mathrm{~S}$ fraction (e.g., Wilk et al. 1985). The proteins designated as $\mathrm{E}$ correspond to the proteins designated as B1C and C2 in Wilk et al. (1985). We propose to refer to them as E proteins for two reasons. First, the designation of these proteins by Wilk et al. (1985) conflicts with the designation of the $\mathrm{C}$ proteins as originally

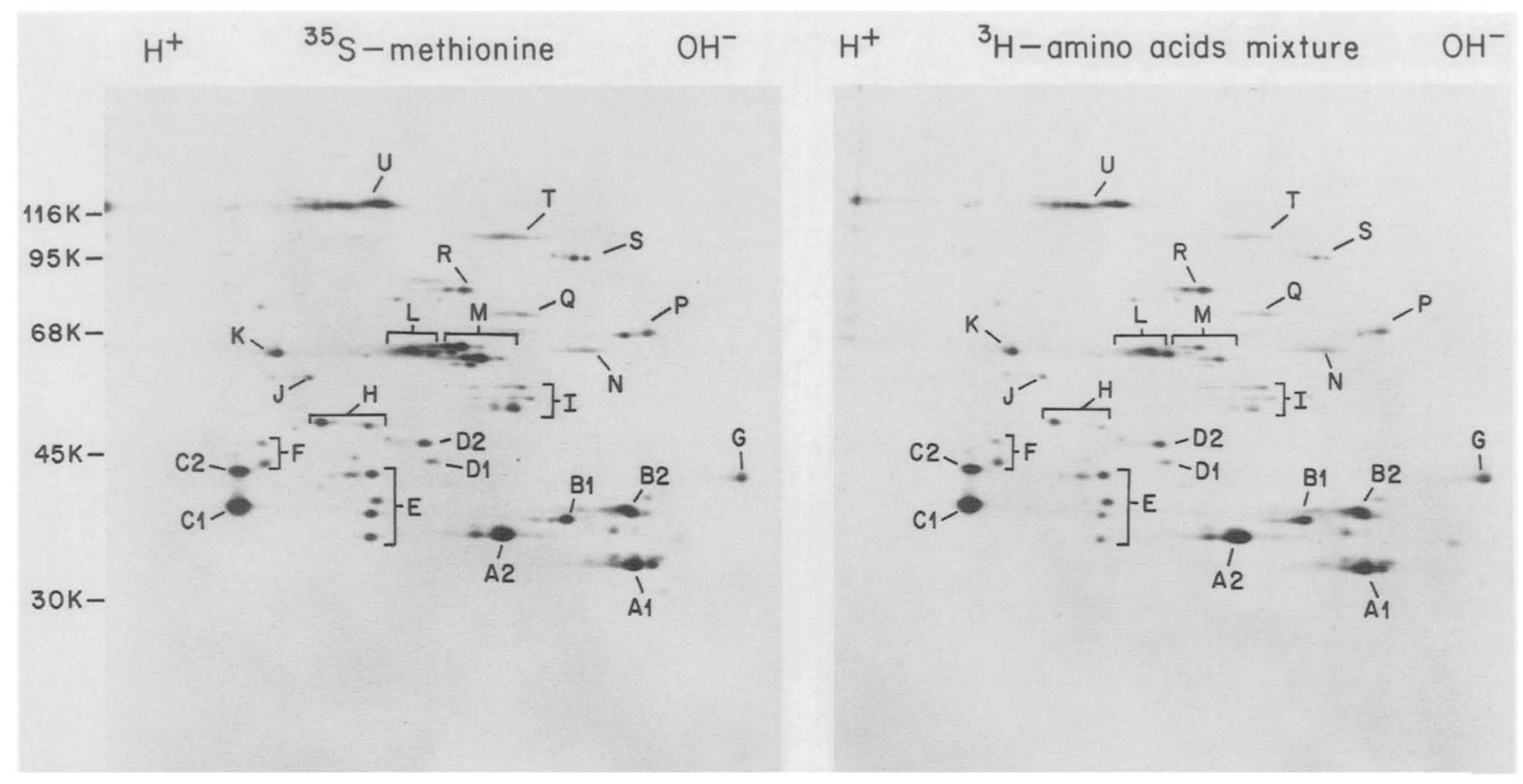

Figure 3. Two-dimensional gel electrophoresis of 4F4-immunopurified hnRNP particles. (Panel $A$ ) $\left[{ }^{35} S\right]$ methionine-labeled proteins; (panel $B$ ) proteins labeled with ${ }^{3} \mathrm{H}$-labeled amino acid mixture, as described in the text. Proteins were resolved in NEPHGE in the first dimension and by SDS-PAGE in the second dimension. 
described by Beyer et al. (1977) and subsequently elaborated on with monoclonal antibodies (Choi and Dreyfuss 1984b; Dreyfuss et al. 1984b), and is therefore confusing. Second, the E proteins are clearly distinct from the A and B proteins, as well as from the $\mathrm{C} 1$ and $\mathrm{C} 2$ proteins, both in amino acid sequence (Lahiri and Thomas 1986) and immunological reactivity (Dreyfuss et al. 1984b; Lahiri and Thomas 1986). Based on comigration on two-dimensional gels of pure UP2 (a gift from Drs. Barbara Merrill and Kenneth Williams), the largest of the E proteins is the mammalian ssDNA-binding protein UP2 (Herrick and Alberts 1976), and it resolves into two isoelectrically distinct spots. We do not have direct evidence that the lower-molecular-weight $\mathrm{E}$ proteins are indeed related to UP2; however, other hnRNP proteins, such as the $C$ and D proteins, with similar isoelectric points and consistent relative labeling intensities, are related. The same rationale was applied in the designation of other protein groups, e.g., F, H, and I. The D proteins, D1 and D2, are also distinct immunologically from the others and are related to each other as they are recognized by the same monoclonal antibody, 5B9 (S. Pinol-Roma and G. Dreyfuss, in prep.). We use the D1, D2 designation for these proteins to be consistent with the designation of Wilk et al. (1985). The amount of the protein designated $\mathrm{G}$ is variable between different preparations, and it probably corresponds to the protein designated by Wilk et al. (1985) as D4, a protein enriched in oligoparticles; it is not, however, related immunologically to the other $\mathrm{D}$ proteins, and so a $\mathrm{D}$ designation for it would be misleading (S. Piñol-Roma and G. Dreyfuss, unpubl.).

The $68 \mathrm{~K}$ protein cluster of about neutral isoelectric point is divided into two groups, $L$ and $M$, because several monoclonal antibodies that we now have indicate that they are distinct (data not shown). The $68 \mathrm{~K} \mathrm{M}$ proteins are labeled less intensely with the ${ }^{3} \mathrm{H}$-labeled amino acid mixture than with $\left.{ }^{35} \mathrm{~S}\right]$ methionine but they are, together with $\mathrm{L}$, some of the major proteins detected by Coomassie blue staining. The $120 \mathrm{~K}$ protein, designated as $U$, is the previously described protein recognized by the monoclonal antibody $3 \mathrm{G} 6$ and is an abundant phosphoprotein (Choi and Dreyfuss 1984b; Dreyfuss et al. 1984b). The A and B proteins are all related to each other and are recognized by antibodies to UP1, the ssDNA-binding $24 \mathrm{~K}$ amino-terminal fragment of Al (Valentini et al. 1985; Riva et al. 1986). The monoclonal antibody iD2 of Leser et al. (1984) also reacts with the A and $\mathrm{B}$ proteins.

\section{Heparin-resistant hnRNP particles}

Intrinsic to the immunopurification procedure used to isolate hnRNP particles is the possibility of an adventitious association of proteins with the particle due simply to the polyanionic character of the hnRNA. Given the complexity of the protein pattern of hnRNP particles, we sought additional criteria for assessing their authenticity and for their classification. This was done by including an incubation step with heparin. Hep- arin is a sulfated proteoglycan that has been used frequently in the study of transcription complexes, and splicing complexes, as a competitor of RNA to dissociate components that interact electrostatically and, thus, possibly nonspecifically with the highly charged RNA in order to facilitate the identification of specific components of these RNA-protein machineries (Konarska and Sharp 1986). Only proteins that interact with the bases of the RNA by strong direct interaction, or with such proteins by strong protein-protein interaction, or those that may be buried in the particles will be expected to remain in the complex after heparin treatment.

hnRNP particles were isolated by immunopurification with 4F4 from nucleoplasm to which heparin had been added at $1 \mathrm{mg} / \mathrm{ml}$. This is a similar concentration to that used recently for the preparation of heparin-resistant splicing complexes (Konarska and Sharp 1986). A comparison of the proteins of hnRNP particles and heparinresistant complexes by two-dimensional gel electrophoresis is shown in Figure 4. By the criterion of retention in heparin-resistant complexes, the $68 \mathrm{~K}$ protein $\mathrm{K}, \mathrm{L}$, and $M$, as well as the $E, D$, and $H$ proteins, are hnRNP proteins, in addition to the $A, B$, and $C$ proteins. In contrast, the proteins $U, N, Q, R, T$, much of $S$, the smaller of the two $F$ proteins, and $G$ dissociate from the particle in the presence of heparin. Little is presently known about these proteins. The proteins that are lost or reduced, however, may still be authentic hnRNP proteins; it could simply be that they have high affinity for heparin or for polyanions in general. This turns out to be the case for the 120K U protein, which binds heparin agarose tightly (unpubl.) and dissociates from ssDNA with heparin (see Fig. 7). Independent evidence shows that the $U$ protein is indeed an authentic hnRNP protein; it is cross-linked to poly $(\mathrm{A})^{+}$nuclear RNA by photochemical cross-linking in vivo, and antibodies against it immunopurify hnRNP particles (Choi and Dreyfuss 1984b; Dreyfuss et al. 1984b|. Titration experiments show that this effect of heparin on the composition of hnRNP complexes is apparent at heparin concentrations of 0.5 $\mathrm{mg} / \mathrm{ml}$ and that there is virtually no further reduction in protein number and amounts at concentrations of up to $2 \mathrm{mg} / \mathrm{ml}$ (data not shown).

The fact that A2 is not at all removed indicates that the effect of heparin is not like salt dissociation because when the $\mathrm{NaCl}$ concentration is raised to $150 \mathrm{mM}$ or higher, A2 together with $\mathrm{A} 1$ is released from the particles (Beyer et al. 1977). It should be noted that although the amount of protein recovered in the immunopurified complexes in the presence of $1 \mathrm{mg} / \mathrm{ml}$ heparin is lower than that of control by up to $30 \%$, the amount of hnRNA recovered is actually higher than in the control (data not shown). This could be due, in part, to effective RNase inhibition by heparin. The loss of the proteins that are removed with heparin is thus not due to loss of RNA from the complexes.

It is interesting that the heparin-resistant complexes behave by sedimentation on sucrose gradients only slightly differently from native particles (Fig. 5). As seen in Figure 5, in agreement with numerous previous ob- 


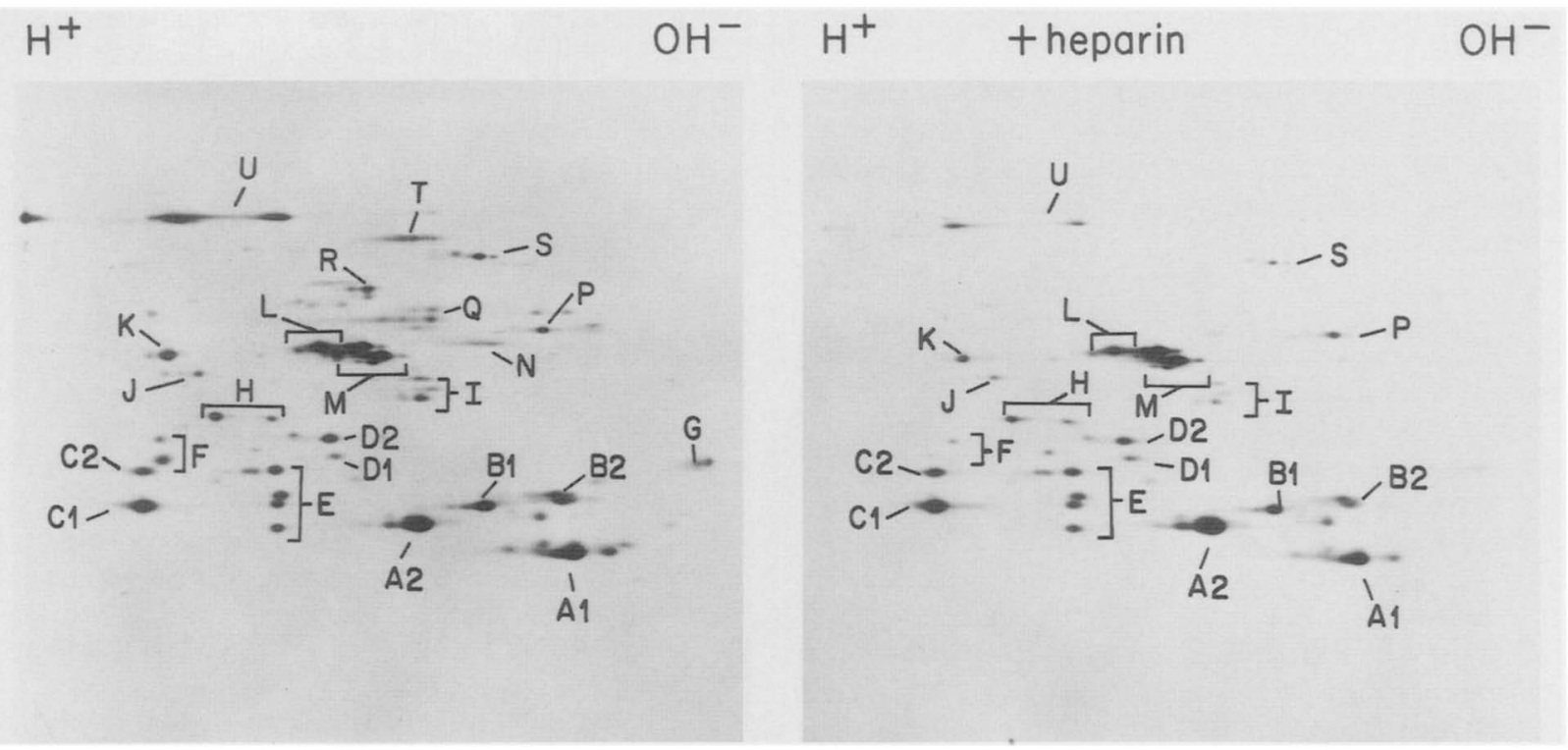

Figure 4. Two-dimensional gel electrophoresis of $\left[{ }^{35} \mathrm{~S}\right]$ methionine-labeled hnRNP particles immunopurified with $4 \mathrm{~F} 4$ in the absence or presence of heparin at $1 \mathrm{mg} / \mathrm{ml}$. The first dimension is NEPHGE, and the second dimension is SDS-PAGE. Procedures for labeling and immunopurification were as described in the legend to Fig. 3.

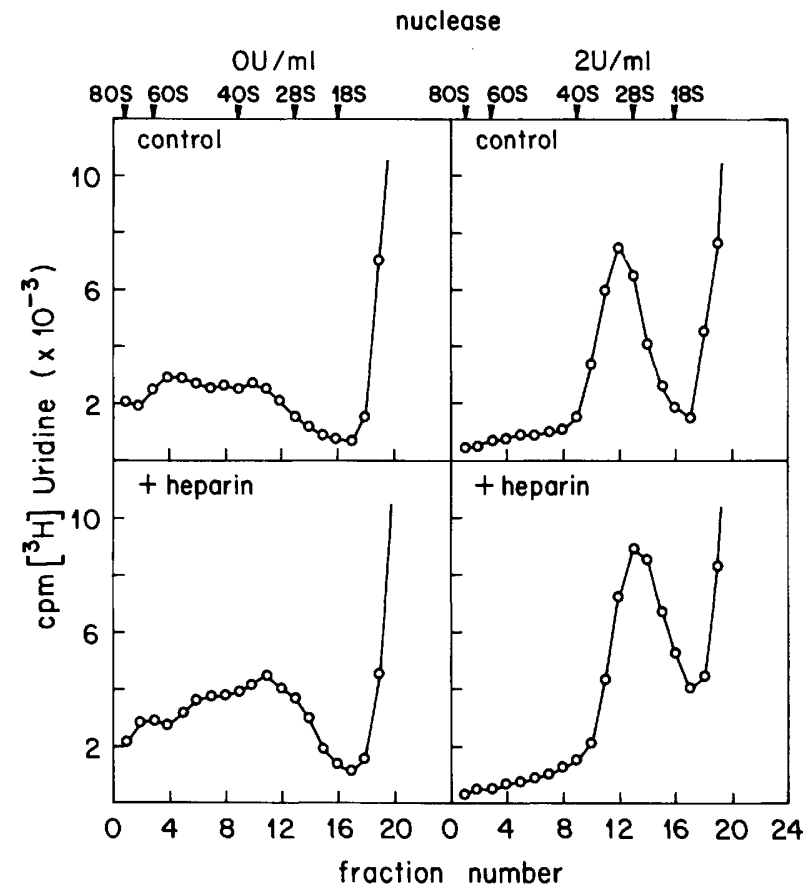

Figure 5. Sucrose gradient sedimentation profiles of heparinresistant hnRNP complexes. Nucleoplasm was incubated with heparin $(1 \mathrm{mg} / \mathrm{ml})$ on ice for $10 \mathrm{~min}$, with or without prior digestion with micrococcal nuclease at 2 units/ml (bottom two panels), and sedimented on $10-30 \%$ sucrose gradients with SW41 rotor at $38,000 \mathrm{rpm}$ for $5 \mathrm{hr}$ at $4^{\circ} \mathrm{C}$. Twenty-four fractions of $500 \mu \mathrm{l}$ were collected from the bottom, and $10-\mu 1$ aliquots were taken for liquid scintillation counting. Sedimentation profiles of undigested and digested nucleoplasm without subsequent heparin treatment are included as control (top two panels). servations (Samarina et al. 1968; Martin et al. 1974 1978; Pederson 1974; Beyer et al. 1977; Karn et al. 1977; Maundrell and Scherrer 1979; Walker et al. 1980; Le Stourgeon et al. 1981; Steitz and Kamen 1981; Lothstein et al. 1985; Wilk et al. 1985), hnRNA sediments in sucrose gradients as heterogeneous material of greater than $30 \mathrm{~S}$ and, after mild digestion with nuclease, as more homogeneous material corresponding to monoparticles at about 30S. Heparin converts the hnRNP particles to slightly slower sedimenting material, but it is evident that particles sedimenting only slightly slower than the control remain. Thus, mostly minor-except for the $U$ protein-probably peripheral components dissociate with heparin. At the same time, however, if strong RNA-binding proteins exist that are not part of hnRNP particles but bind to the hnRNA during cell fractionation, they may not dissociate from the complex with heparin. Nevertheless, proteins that remain in the heparin-resistant complex can be judged to be authentic by a more stringent criterion than that used in previous studies, and these remain together in a discrete particle.

\section{Affinity chromatography purification of hnRNP proteins on ssDNA}

It has recently been shown that the mammalian ssDNA-binding protein UP1 (Herrick and Alberts 1976) is a fragment of the hnRNP protein Al (Valentini et al. 1985; Riva et al. 1986). Another major ssDNA-binding protein, UP2, also turned out to be an hnRNP protein (E, discussed above). Therefore, it seemed possible that other hnRNP proteins may also have the property of binding to single-stranded nucleic acids [ssRNA and 
ssDNA) and that chromatography on ssDNA-agarose could be used for their purification. ssDNA, rather than ssRNA, is a preferable substrate for chromatography of single-stranded nucleic acids-binding proteins because of the greater stabilty of the ssDNA column. In an attempt to separate and enrich for different hnRNP proteins, nucleoplasm from HeLa cells labeled with $\left[{ }^{35} \mathrm{~S}\right] \mathrm{me}$ thionine was fractionated on ssDNA-agarose columns after digestion with micrococcal nuclease (Fig. 6). The proteins were applied to the column at $100 \mathrm{~mm} \mathrm{NaCl}$ and eluted stepwise with increasing $\mathrm{NaCl}$ concentrations (Fig. 6A), with a final wash of $4 \mathrm{M}$ guanidine- $\mathrm{HCl}$. The results show that most of the hnRNP proteins indeed remain bound to the ssDNA-agarose and elute from the column at different salt concentrations; A2, B1, $\mathrm{I}$, and $\mathrm{S}$ are the major proteins eluting at $0.3 \mathrm{M} \mathrm{NaCl}$. The bulk of Al, Bl, E, F, K, L, P, and $\mathrm{U}$ elute at $0.5 \mathrm{M} \mathrm{NaCl}$. Some of the $\mathrm{D}$ proteins also elute at $0.5 \mathrm{M} \mathrm{NaCl}$. Finally, the $C$ proteins are the major proteins eluting at $2 \mathrm{M}$, together with residual amounts of the $\mathrm{D}$ proteins and smaller amounts of proteins at $68 \mathrm{~K}$, which are most likely $L$ and $M$. Because of the effect of heparin on hnRNP proteins discussed above, we have also examined the effect of heparin on the ssDNA chromatography. Inclusion of a heparin wash step (Fig. 6B) results in removal of most proteins that otherwise elute at $0.2 \mathrm{M}$ $\mathrm{NaCl}$, and the pattern of proteins eluted after the heparin wash remains much the same. Because heparin is a sulfated polyanion, it can be expected that the observed retention of the bound proteins after the heparin wash is a result of their interaction with the bases and not with the polyphosphate backbone of the ssDNA. We cannot completely rule out, however, that some proteins are retained on the column indirectly because of strong protein-protein interaction with a ssDNA-binding protein. The most striking consequence of the heparin wash is the complete removal of the $\mathrm{U}$ protein, which otherwise requires $0.5 \mathrm{M} \mathrm{NaCl}$ for elution (Fig. 6A), in agreement with the data shown above describing the dissociation of the U protein from heparin-resistant hnRNP particles. Furthermore, the removal of the $U$ protein with heparin indicates that this is not due primarily to a salt dissociation because one would otherwise expect most of the remaining proteins eluting at salt concentrations of up to $0.5 \mathrm{M}$ to also be removed in the heparin wash. In contrast, most of the remaining proteins interact with the ssDNA in a heparin-resistant manner. The identity of $\mathrm{Al}, \mathrm{C}$ proteins, and $\mathrm{U}$ was confirmed by immunoblotting of parallel gels with monoclonal antibodies against $\mathrm{A} 1$ (4B10), $\mathrm{C} 1$ and $\mathrm{C} 2$ (4F4), and U (3G6) (Fig. 7). From comparison of Figures 6 and 7, it seems that $4 \mathrm{~B} 10$ reacts with a subpopulation of $\mathrm{A} 1$, preferentially that which elutes from ssDNA at $0.3 \mathrm{M} \mathrm{NaCl}$. The identity of most of the other proteins was confirmed by two-dimensional gel analysis of the individual fractions and by immunoblotting, and the data are summarized in Table 1. The

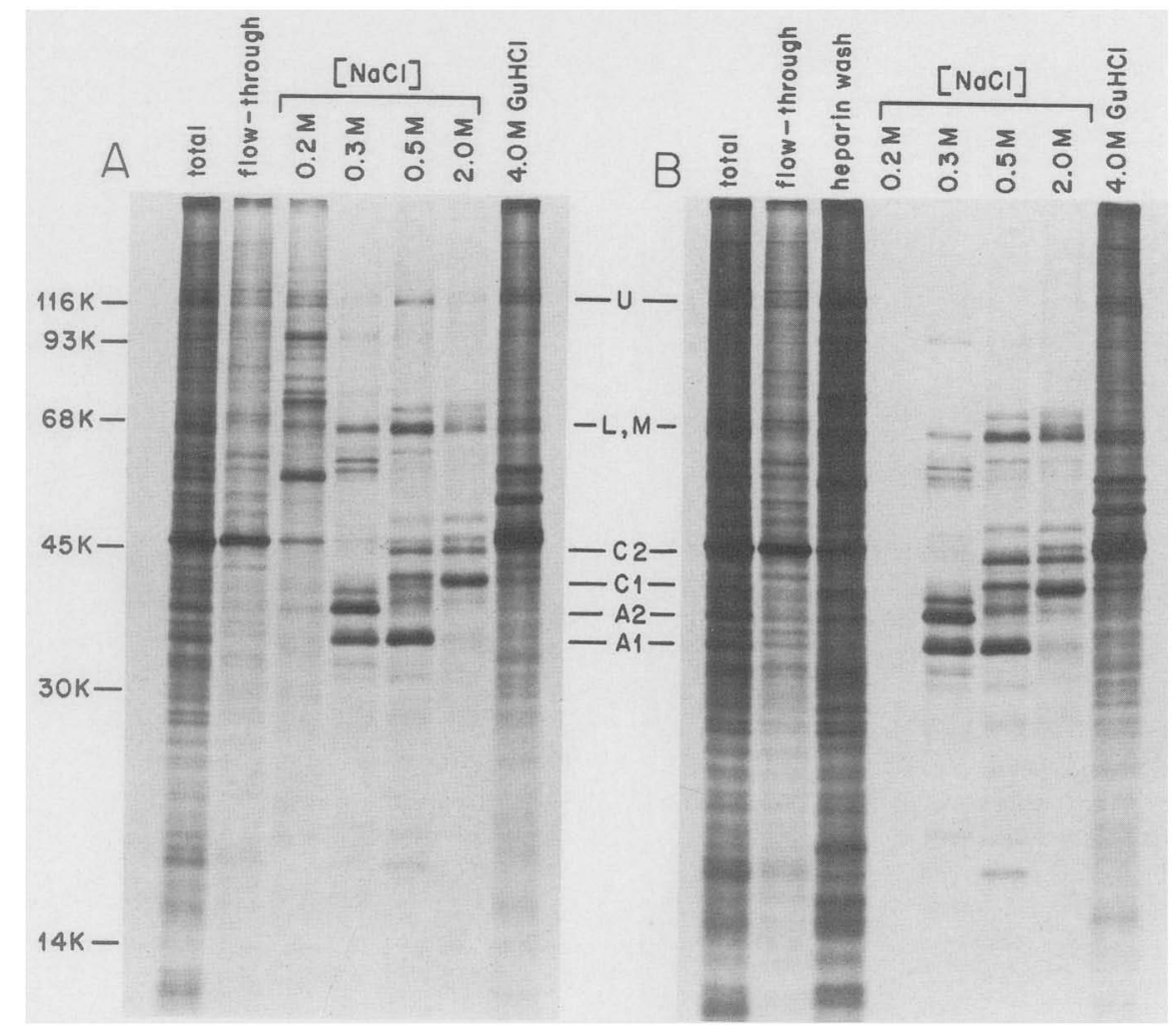

Figure 6. ssDNA-agarose chromatography of nucleoplasm. Micrococcal nuclease-digested nucleoplasm was fractionated by ssDNA-agarose chromatography, as described in Materials and methods. The $\left[{ }^{35} \mathrm{~S}\right]$ methionine-labeled proteins eluted at various $\mathrm{NaCl}$ concentrations were analyzed by SDS-PAGE (panel $A$ ). (Panel $B$ ) The results obtained by ssDNA chromatography run in parallel to those shown in panel $A$, which also included a wash with heparin at $1 \mathrm{mg} / \mathrm{ml}$ prior to elution with $0.2 \mathrm{M} \mathrm{NaCl}$. 


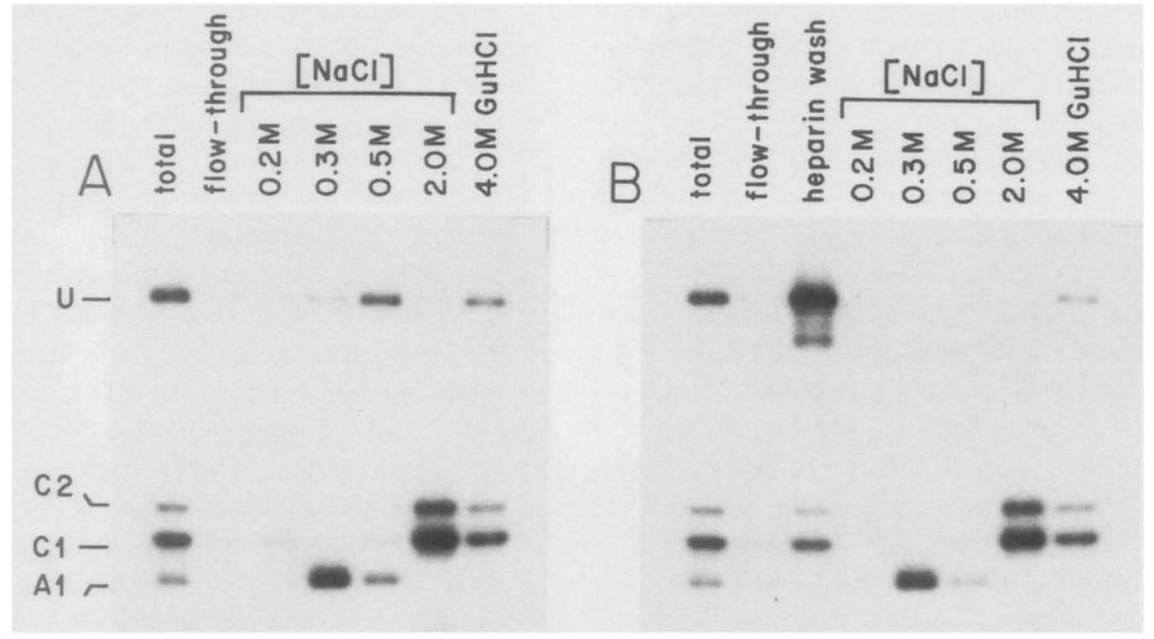

Figure 7. Immunoblot analysis of ssDNA-agarose chromatography. Gels identical to those shown in Fig. 6 were transferred to nitrocellulose and incubated with monoclonal antibodies 4F4 (anti-C), 4B10 (anti-A1), and 3G6 (anti-U), followed by incubation with 125I-labeled goat anti-mouse. The positions of $\mathrm{A} 1, \mathrm{C} 1, \mathrm{C} 2$, and $\mathrm{U}$ are indicated.

relative affinity of the different hnRNP proteins for ssDNA, as determined from the salt concentration required to elute them from the ssDNA column, closely parallels their affinity for RNA as determined from salt dissociation experiments with immunopurified hnRNP particles (data not shown). A variable, but usually considerable, amount of protein is retained in the column even after elution with $2 \mathrm{M} \mathrm{NaCl}$, and it is removed only by the $4 \mathrm{M}$ guanidine- $\mathrm{HCl}$ wash. This, however, does not necessarily indicate that these proteins have an extremely high affinity for ssDNA. Many hnRNP proteins have a tendency to aggregate, especially when the RNA is removed, and it is possible that most of the proteins in the guanidine $-\mathrm{HCl}$ wash are components of aggregates that form on the column during the chromatographic procedure.

Table 1. Proteins of hnRNP particles

\begin{tabular}{|c|c|c|c|c|}
\hline Protein & $\begin{array}{l}\text { Molecular } \\
\text { weight }(\mathrm{kD})\end{array}$ & $\begin{array}{l}\text { Isoelectric } \\
\text { point }^{\mathbf{a}}\end{array}$ & $\begin{array}{l}\text { Heparin } \\
\text { resistance }\end{array}$ & $\begin{array}{l}\text { ssDNA dissociation } \\
(\mathrm{M} \mathrm{NaCl})^{\mathrm{c}}\end{array}$ \\
\hline$\overline{\mathrm{A} 1}$ & 34 & $9.0-9.1$ & + & $0.3-0.5$ \\
\hline $\mathrm{A} 2$ & 36 & 8.4 & + & 0.3 \\
\hline B1 & 38 & 8.8 & + & $0.3-0.5$ \\
\hline B2 & 39 & 9.0 & + & 0.5 \\
\hline $\mathrm{Cl}$ & 41 & 5.9 & + & $1-2$ \\
\hline $\mathrm{C} 2$ & 43 & 5.9 & + & $1-2$ \\
\hline D1 & 44 & 7.8 & + & 0.5 \\
\hline $\mathrm{D} 2$ & 48 & 7.7 & + & 0.5 \\
\hline $\mathrm{E}$ & $36-43$ & 7.3 & + & 0.5 \\
\hline $\mathrm{F}$ & 44,49 & 6.1 & $+1-$ & 0.5 \\
\hline G & 43 & 9.5 & $+1-$ & N/A \\
\hline $\mathrm{H}$ & 56 & $6.7-7.1$ & + & N/A \\
\hline I & 59 & 8.5 & $+1-$ & 0.3 \\
\hline $\mathrm{J}$ & 62 & 6.7 & + & N/A \\
\hline $\mathrm{K}$ & 68 & $6.1-6.4$ & + & 0.5 \\
\hline $\mathrm{L}$ & 68 & $7.4-7.7$ & + & 0.5 \\
\hline M & 68 & $7.8-8.2$ & + & N/A \\
\hline $\mathrm{N}$ & 70 & $8.7-8.9$ & - & N/A \\
\hline $\mathrm{P}$ & 72 & 9.0 & + & 0.5 \\
\hline $\mathrm{Q}$ & $76-77$ & 8.3 & - & N/A \\
\hline $\mathrm{R}$ & 82 & 8.0 & - & N/A \\
\hline S & 105 & 8.8 & - & 0.3 \\
\hline $\mathrm{T}$ & 113 & 8.4 & - & N/A \\
\hline $\mathrm{U}$ & 120 & $6.6-7.2$ & - & 0.5 \\
\hline
\end{tabular}

a Estimated from NEPHGE two-dimensional gels (Fig. 3).

b Determined from two-dimensional gels at $1 \mathrm{mg} / \mathrm{ml}$ heparin (Fig. 4).

c Determined from two-dimensional gels or from immunoblotting of one-dimensional gels with specific antibodies; (N/A) not available. 
The usefulness of affinity chromatography purification of hnRNP proteins on ssDNA is apparent when comparing protein eluted batchwise with $2 \mathrm{M} \mathrm{NaCl}$ following a heparin wash $(1 \mathrm{mg} / \mathrm{ml})$ at $100 \mathrm{mM} \mathrm{NaCl}$, and those present in 4F4-immunopurified hnRNP particles. Two-dimensional gel electrophoresis analysis of both sets of proteins reveals a striking similarity in their composition (Fig. 8). Most hnRNP proteins are present in the $2 \mathrm{~m} \mathrm{NaCl}$ eluate from the ssDNA column, with the exception of the relatively minor N, R, T and, possibly, $\mathrm{Q}$ proteins, which are also absent from immunopurified heparin-resistant hnRNP particles (see above). The major ssDNA-binding proteins (e.g., A and B group, C proteins, E, D, K, L, and M) are also the major proteins in heparin-resistant hnRNP particles. Although the relative abundance of the major proteins in the two sets is remarkably similar, there are some apparent differences. The I, K, and the two slower migrating E proteins are present in larger relative amounts in ssDNA affinity-purified hnRNP proteins than in immunopurified particles. The $\mathrm{H}$ proteins, the two faster migrating $\mathrm{E}$ proteins, and the larger $\mathrm{F}$ protein are present in lower relative amounts in ssDNA affinity-purified proteins than in heparin-resistant immunopurified hnRNP particles. The material from the ssDNA column probably reflects more closely the actual amounts of these proteins in the cell. All of the few qualitative differences between the two sets of proteins, aside from those reflecting heparin-resistant hnRNP proteins, correspond to minor spots in the ssDNA affinity-purified proteins. Some of the proteins in the ssDNA-column $2 \mathrm{~m}$ fraction that are not detected in immunopurified particles may correspond to genuine RNA-binding proteins, which are nevertheless not in hnRNP particles. This is the case for two proteins apparent in the $2 \mathrm{M} \mathrm{NaCl}$ eluate, with slightly lower apparent molecular weight and slightly higher pI than D1 and D2, which are immunologically related to these $D$ proteins and are indeed in contact with poly $(\mathrm{A})^{+} \mathrm{RNA}$ in vivo (data not shown). The remaining proteins that are absent from immunopurified particles may reflect nonparticle-associated modifications of genuine hnRNP proteins, degradation products due to the lengthier process of affinity chromatography, and/or other kinds of non-RNP, ssDNA-binding proteins. In general, affinity chromatography on ssDNA columns seems to be an excellent step for the purification of hnRNP proteins. We have taken advantage of this method to purify and produce monoclonal antibodies to $\mathrm{Al}$ (4B10), as described in Materials and methods, as well as to D1 and D2 and to the $\mathrm{L}$ protein.

\section{Discussion}

The immunopurification of the hnRNP complex described here and in a previous report (Choi and Dreyfuss 1984a) enables the identification and definition of its components with greater detail and certainty than was possible before now. The immunopurification procedure has a number of advantages over other methods traditionally used for studying hnRNP complexes such as sucrose gradient sedimentation of $30 \mathrm{~S}$ particles and photochemical cross-linking of proteins to RNA. It circum-

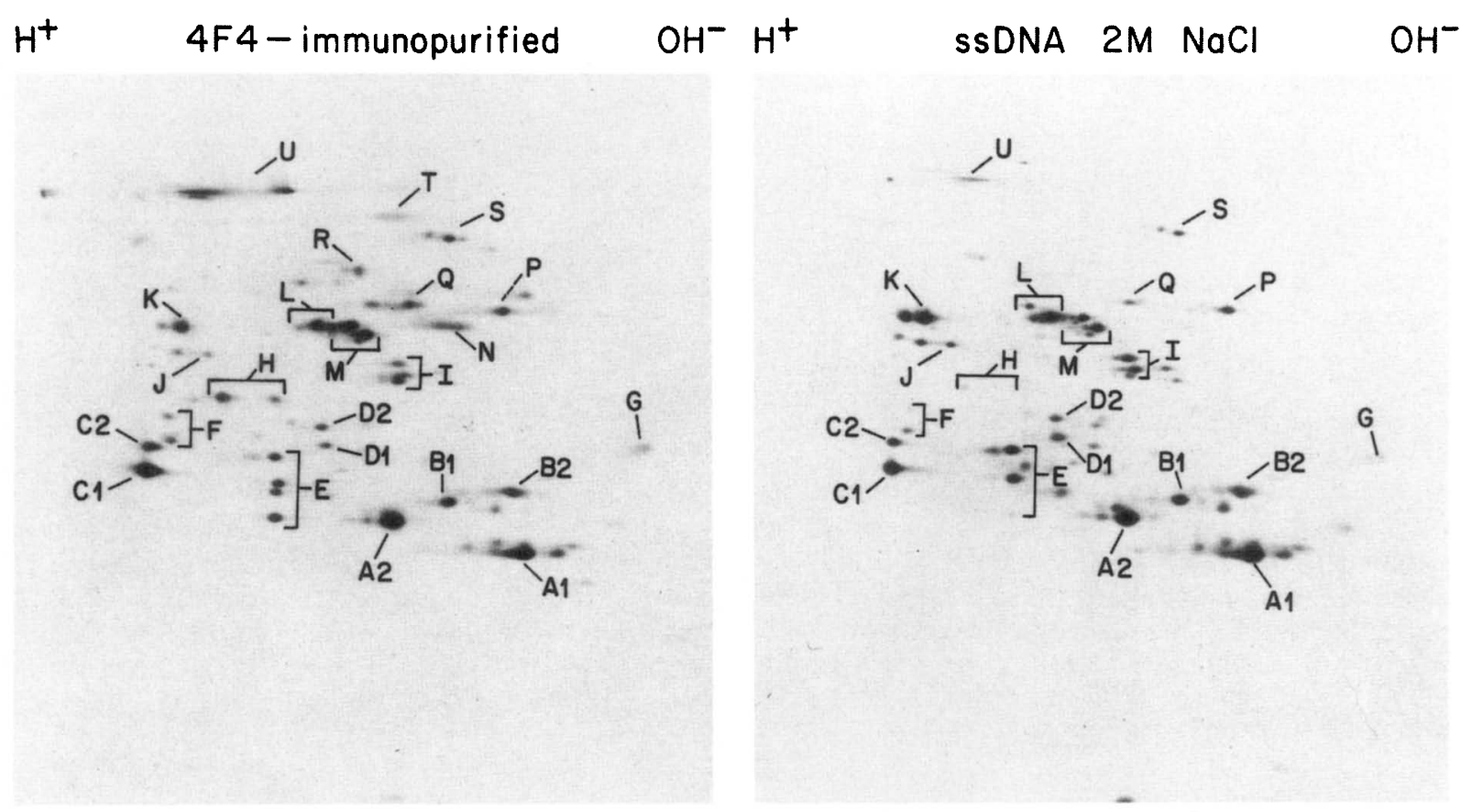

Figure 8. Comparison of 4F4-immunopurified hnRNP particles and hnRNP proteins purified by affinity chromatography on ssDNA. Nucleoplasm proteins from HeLa cells labeled with $\left[{ }^{35} \mathrm{~S} \mid\right.$ methionine were eluted from a ssDNA-agarose column with $2 \mathrm{M} \mathrm{NaCl}$, following a heparin wash, and analyzed by two-dimensional gel electrophoresis (right panel). 4F4-immunopurified hnRNP particles (left panel). 
vents the need to radioactively label the hnRNA in order to identify the hnRNP-containing fraction; it does not depend on RNase cleavage of the RNA and, thus, yields hnRNP particles with intact transcripts; it is rapid and gentle, minimizing proteolysis and disruption of the complex and thereby loss of genuine components; and, most importantly, it is highly specific by the very nature of the monoclonal antibody reagents used. The results obtained are highly reproducible in terms of protein composition and stoichiometry, and virtually identical results have been obtained with monoclonal antibodies against at least seven different hnRNP proteins. Unlike the photochemical cross-linking procedure, the immunopurification procedure preserves the proteins in native form and in apparently normal relative abundance because the different efficiency of cross-linking of the various proteins is not a factor. The purity of the immunopurified hnRNP complexes is obvious by the absence of abundant nuclear proteins such as histones. We have not been able to detect, under the conditions used here, the presence of significant amounts of other RNP proteins, such as those of small nuclear RNPs (snRNPs). However, it should be emphasized that, as in any cellular fractionation procedure, one cannot completely exclude the possibility that some components associate with the complex during the fractionation but are not part of it in vivo. It is also possible that additional authentic proteins of the complex exist in the cell but dissociate from the complex during the fractionation procedure. Nevertheless, by means of photochemical crosslinking, we have been able to determine that every protein described here for which we have specific monoclonal antibody probes $(\mathrm{A} 1, \mathrm{C} 1, \mathrm{C} 2, \mathrm{D} 1, \mathrm{D} 2, \mathrm{~L}, \mathrm{M}$, and $\mathrm{U}$ ) is indeed in contact with hnRNA in vivo (Dreyfuss et al. 1984b; data not shown).

Our results show that hnRNP particles are composed of an assortment of at least 24 distinct polypeptides. The designation we use for these proteins and a summary of some of their characteristics are presented in Table 1. The designation of some of the proteins may need to be revised in the future, as new monoclonal antibody probes and amino acid sequence data may reveal either additional differences or relationships among these proteins that we are unable to determine at this stage. The fact that most of these proteins, except for the $U$ protein and some minor components, remain associated as heparin-resistant particles reaffirms their authenticity as genuine hnRNP proteins. Although the $120 \mathrm{~K} \mathrm{U}$ protein dissociates from the hnRNP particles with heparin, it has nevertheless been shown to be an authentic hnRNP component by the criteria of UV cross-linking in vivo and by the ability of a monoclonal antibody against it (3G6) to immunopurify the same set of proteins as does 4F4 (Dreyfuss et al. 1984b). It may be that $U$ protein has high affinity for heparin. The complex composition of hnRNP particles we observe here is in contrast with the frequent description of hnRNP particles as composed of multiples of six 30-40K A, B, and C proteins with several minor higher-molecular-weight proteins (for review, see LeStourgeon et al. 1981; Chung and Wooley 1986). It is apparent that the proteins other than $\mathrm{A} 1, \mathrm{~A} 2, \mathrm{~B} 1, \mathrm{C} 1$, and $\mathrm{C} 2$, including the high-molecular-weight proteins, are not merely minor components but rather abundant constituents of hnRNP particles. Most of the major proteins are evident in several published electrophoretic gels of 30 S particles (e.g., Wilk et al. 1985), but they had not been named or otherwise discussed previously in such studies because it could not be concluded that they were components of hnRNP particles as opposed to cosedimenting non-hnRNP material. Immunopurification and two-dimensional electrophoretic analysis of monoparticles generated by mild digestion with micrococcal nuclease under conditions that generate $30 \mathrm{~S}$ particles indicates that most of the proteins remain together in particles; only the I, P, and S proteins are released from these complexes (data not shown). Another conclusion that can be drawn from the analysis presented here is that one-dimensional SDS-PAGE analysis of hnRNP particles is not sufficient for most purposes, even for observations of the $\mathrm{A}, \mathrm{B}$, and $\mathrm{C}$ proteins, because clearly different proteins comigrate in SDS-PAGE, e.g., the $\mathrm{E}$ and $\mathrm{G}$ proteins with $\mathrm{A} 2, \mathrm{~B} 1, \mathrm{~B} 2, \mathrm{C} 1$, and $\mathrm{C} 2$. For most studies, either two-dimensional gel electrophoresis or one-dimensional analysis with use of specific antibodies is necessary. Of the proteins for which amino acid sequence information is available so far, A1, A2, E, C1, and $\mathrm{C} 2$ have the conserved RNP consensus sequence (Adam et al. 1986; Swanson et al. 1987), and it is likely that the A group-related B proteins, as well as other proteins in the complex, will also contain it.

In view of the complexity of the protein composition of hnRNP particles, it becomes apparent that the availability of specific monoclonal antibody probes against individual proteins should greatly facilitate studies on the overall structure of the complex, as well as on the structure and function of the individual components. For instance, monoclonal antibodies against the $\mathrm{C}$ proteins have made it possible to establish a role for these proteins in pre-mRNA splicing (Choi et al. 1986). The method of fractionation and large-scale purification of hnRNP proteins by ssDNA-agarose affinity chromatography has enabled us to obtain large amounts of partially purified hnRNP proteins to produce the monoclonal antibody $4 \mathrm{~B} 10$ against the $\mathrm{A} 1$ protein, as well as monoclonal antibodies against the $\mathrm{D} 1, \mathrm{D} 2$, and L proteins. This isolation procedure for hnRNP proteins has the advantage of not requiring isolation of intact hnRNP particles, and it is therefore simpler and results in high yields. The specificity of the procedure is highlighted by a comparison of the composition of the $2 \mathrm{M} \mathrm{NaCl}$ eluate from the ssDNA column with the composition of immunopurified hnRNP particles. This affinity chromatography procedure indicates that most, if not all, of the proteins described are indeed single-stranded nucleic acid-binding proteins. ssDNA-agarose chromatography has also proved to be a useful analytical tool, given the high degree of correlation between the elution profile of the different proteins and their affinity for RNA /Y.D. Choi, S. Piñol-Roma, and G. Dreyfuss, in prep.). In addition, we have been able to use this fractionation proce- 
dure as a highly efficient step for the purification of the $C$ proteins in order to carry out biochemical studies (unpubl.). While this manuscript was in preparation, Pandolfo et al. (1987) also reported on the isolation of several hnRNP proteins $(34-43 \mathrm{~K}$ and related $53-55 \mathrm{~K}$ proteins) by affinity chromatography on ssDNA.

\section{Materials and methods}

\section{Cell culture and labeling}

HeLa S3 (human) cells were cultured in monolayer to subconfluent densities in Dulbecco's modified Eagle's (DME) medium, supplemented with penicillin and streptomycin and containing $10 \%$ fetal calf serum at $37^{\circ} \mathrm{C}$. Cells were labeled with ${ }^{35} \mathrm{~S} \mid \mathrm{me}$ thionine at $20 \mu \mathrm{Ci} / \mathrm{ml}$ for $20 \mathrm{hr}$ in DME medium containing one-tenth the normal methionine level and $5 \%$ fetal calf serum, or with a mixture of ${ }^{3} \mathrm{H}$-labeled amino acids (Amersham) at 50 $\mu \mathrm{Ci} / \mathrm{ml}$ in medium containing one-tenth the normal level of amino acids and $5 \%$ fetal calf serum.

\section{Cell fractionation}

Procedures for preparation of the nucleoplasmic fraction were essentially according to Pederson (1974), as previously detailed (Choi and Dreyfuss 1984a). All steps were carried out at $0-4^{\circ} \mathrm{C}$ as rapidly as possible. The culture medium was removed and the cell monolayers were washed twice with cold phosphatebuffered saline $(\mathrm{Pi} / \mathrm{NaCl})$. Cells were scraped with a rubber policeman in $1 \mathrm{ml} / 10 \mathrm{~cm}$ plate of cold buffer A $/ 10 \mathrm{mM}$ Tris- $\mathrm{HCl}$ at $\mathrm{pH} 7.4 / 100 \mathrm{~mm} \mathrm{NaCl} / 2.5 \mathrm{~mm} \mathrm{MgCl}_{2}$ ), containing $0.5 \%$ aprotinin (Sigma), $2 \mu \mathrm{g} / \mathrm{ml}$ of pepstatin A, $2 \mu \mathrm{g} / \mathrm{ml}$ of leupeptin, $0.5 \%$ Triton X-100 and homogenized by four passages through a 25 -gauge needle. The nuclei were separated by a brief spin at $3000 \mathrm{~g}$, resuspended in $0.5 \mathrm{ml}$ of cold buffer A containing $0.5 \%$ aprotinin, $2 \mu \mathrm{g} / \mathrm{ml}$ of pepstatin $\mathrm{A}$, and $2 \mu \mathrm{g} / \mathrm{ml}$ of leupeptin, and sonicated twice for $5 \mathrm{sec}$ each using a microtip sonicator (model w-220 F, Heat System/Ultrasonics, Plainview, NY), set at scale 2 , on ice. The sonicate was layered on a $30 \%$ sucrose cushion in buffer $A$ and centrifuged at $5000 \mathrm{rpm}(4000 \mathrm{~g})$ for $15 \mathrm{~min}$ in the HS-4 rotor in a Sorvall RC5 centrifuge to remove chromatin and nucleoli. The supernatant fraction, operationally defined as the nucleoplasm, was taken and used for immunoprecipitation. In the hnRNP recovery experiment, the chromatin pellet or nuclei was resuspended with $0.5 \mathrm{ml}$ of buffer A containing the proteinase inhibitors and digested with 5 units/ml of RNase Tl (Pharmacia) at $30^{\circ} \mathrm{C}$ for $10 \mathrm{~min}$, and the insoluble fraction was separated by overlay on a $30 \%$ sucrose cushion as described above.

\section{RNase digestion}

Digestions of the nucleoplasmic fraction were carried out with micrococcal nuclease (P-L Biochemicals) at 2 units $/ \mathrm{ml}$ or 100 units $/ \mathrm{ml}$ for $10 \mathrm{~min}$ at $30^{\circ} \mathrm{C}$ in the presence of $1 \mathrm{~mm} \mathrm{CaCl} 2$. The reactions were stopped by adding EGTA to a final concentration of $5 \mathrm{mM}$, on ice. RNase $\mathrm{T} 1$ digestions were as described above.

\section{Preparation of monoclonal antibodies}

The monoclonal antibody $4 \mathrm{~F} 4$ to the $\mathrm{C}$ proteins was prepared as described previously (Choi and Dreyfuss 1984b). The anti-Al monoclonal antibody 4B10 was prepared by immunizing a NZB mouse (Frosch et al. 1985) with partially purified HeLa Al.
HeLa S3 nucleoplasm (from $\sim 1 \times 10^{9}$ cells) was loaded onto a DEAE-Sephacel column (Sigma) at $100 \mathrm{mM} \mathrm{NaCl}$ in $50 \mathrm{~mm}$ Tris- $\mathrm{HCl}(\mathrm{pH} 7.4)$. The flow-through was collected and further fractionated on a ssDNA column as described below, without a heparin wash. The fraction eluting at $0.5 \mathrm{M} \mathrm{NaCl}$ was used as the antigen. Hybridomas were produced by fusion with the mouse myeloma cell line SP2/0 as described (Dreyfuss et al. $1984 \mathrm{~b})$. Ascites fluid of $4 \mathrm{~B} 10$ was prepared by intraperitoneal inoculation of X-ray irradiated BALB/c mice (Frosch et al. 1985).

\section{Immunoprecipitation and immunopurification of hnRNP complexes}

The hnRNP complex was immunopurified from the nucleoplasm as described previously (Choi and Dreyfuss 1984a) for 10 min at $4^{\circ} \mathrm{C}$ with the anti-C protein monoclonal antibody $4 \mathrm{~F} 4$ or anti-Al monoclonal antibody $4 \mathrm{~B} 10$ bound to protein $\mathrm{A}$ agarose. These monoclonal antibodies bind to Staphylococcus aureus protein A directly. The ascites fluid containing the antibody was passed though an aminophenylphosphouridine $2^{\prime}\left(3^{\prime}\right)$ phosphate-agarose column to remove contaminating RNase (Maxwell et al. 1977), and then $2.5 \mu \mathrm{l}$ of the antibody was bound to $25 \mu \mathrm{l}$ of protein A-agarose (Boehringer Mannheim) for $1 \mathrm{hr}$ at $4^{\circ} \mathrm{C}$ in buffer A containing $0.5 \%$ Triton X-100. The antibody-protein A-agarose complex was washed three times with buffer $\mathrm{A}$ and incubated with nucleoplasm for $10 \mathrm{~min}$ at $4^{\circ} \mathrm{C}$ with gentle rocking. The beads were washed five times by resuspension in 1-ml aliquots of the same buffer, and the bound material was eluted from the agarose beads with $50 \mu \mathrm{l}$ of SDSPAGE sample buffer (Dreyfuss et al. 1984a) or NEPHGE sample buffer (see below) for protein analysis. Immunoprecipitation with ascites fluid of a BALB/c mouse that was inoculated intraperitoneally with the parent myeloma line SP2/0 and treated as described above for the ascites fluids containing the monoclonal antibodies was included as a nonimmune control with each experiment. Amounts of SP2/0 ascites fluid that contained similar quantities of mouse (nonimmune) IgG to that found in the monoclonal antibody preparations, as judged by Coomassie blue staining, were used. The specificities of the antibodies were confirmed by immunoblotting and by immunoprecipitation in the presence of the ionic detergent Empigen $\mathrm{BB}$ at $1 \%, 1$ mM EDTA, and 0.1 mM DTT as described (Choi and Dreyfuss 1984b). Where indicated, nucleoplasm was incubated with the appropriate amounts of heparin for $10 \mathrm{~min}$ on ice prior to incubation with the antibody-protein A-agarose complex. The same amount of heparin was also included in the first wash of the beads.

\section{Gel electrophoresis and immunoblotting}

Protein samples were electrophoresed on a SDS-containing discontinuous PAGE system (SDS-PAGE) (Dreyfuss et al. 1984a). The separating gel had a final acrylamide concentration of $12.5 \%$. After electrophoresis of $\left.{ }^{35} \mathrm{~S}\right]$ methionine-labeled material, the gel was stained with Coomassie blue and impregnated with 2,5-diphenyloxazole for fluorography (Laskey and Mills 1975). Two-dimensional NEPHGE was carried out by the procedure of O'Farrell et al. (1977). The first dimension was separated by using pH 3-10 ampholine gradients for $4 \mathrm{hr}$ at $400 \mathrm{~V}$, and the second dimension was by SDS-PAGE as described above. Immunoblotting procedures were as described previously (Choi and Dreyfuss 1984b).

\section{Sucrose gradient sedimentation}

Sucrose gradients $(10-30 \%$, wt/vol $)$ were sedimented in a 
Beckman SW41 rotor at $38,000 \mathrm{rpm}$ for $5 \mathrm{hr}$ at $4^{\circ} \mathrm{C}$. RNA was labeled with $\left[{ }^{3} \mathrm{H}\right]$ uridine $(50 \mu \mathrm{Ci} / \mathrm{ml})$ for $15 \mathrm{~min}$ in the presence of actinomycin $\mathrm{D}(0.04 \mu \mathrm{g} / \mathrm{ml})$ added $15 \mathrm{~min}$ prior to labeling. Twenty-four fractions $(0.5 \mathrm{ml}$ each) were collected from the bottom, and a 10- $\mu$ l aliquot of each fraction was taken for liquid scintillation counting. Sucrose solutions were made up of 10 $\mathrm{mM}$ Tris- $\mathrm{HCl}(\mathrm{pH} 7.4)$ buffer containing $100 \mathrm{mM} \mathrm{NaCl}$ and 2.5 $\mathrm{mM} \mathrm{MgCl}_{2}$. The $28 \mathrm{~S}$ ribosomal marker was from phenol-extracted cytoplasmic fraction sedimented similarly in the presence of $10 \mathrm{mM}$ EDTA (instead of $\mathrm{MgCl}_{2}$ ).

\section{Affinity chromatography on ssDNA-agarose columns}

Nucleoplasm was digested with 100 units $/ \mathrm{ml}$ of micrococcal nuclease for $15 \mathrm{~min}$ at $30^{\circ} \mathrm{C}$, as described above. The digested sample was divided into two aliquots, and each was loaded onto a separate 1-ml ssDNA-agarose column (Bethesda Research Laboratories) equilibrated with $100 \mathrm{~mm} \mathrm{NaCl}$ in buffer $\mathrm{P}$ (50 mM Na phosphate at $\mathrm{pH}$ 7.4). The flow-through was collected, the column was washed with 20 volumes of the same buffer, and elutions were performed with 10-column volumes of each of the following buffers: $0.2 \mathrm{M} \mathrm{NaCl}, 0.3 \mathrm{M} \mathrm{NaCl}, 0.5 \mathrm{M} \mathrm{NaCl}$, $2.0 \mathrm{M} \mathrm{NaCl}$, and $4.0 \mathrm{M}$ guanidine- $\mathrm{HCl}$, all in buffer $\mathrm{P}$. Where indicated, a wash with heparin at $1.0 \mathrm{mg} / \mathrm{ml}, 0.1 \mathrm{M} \mathrm{NaCl}$ in buffer $\mathrm{P}$ was included prior to the $0.2 \mathrm{M} \mathrm{NaCl}$ wash. Column fractions were monitorerd by liquid scintillation counting, and peak fractions for each elution were pooled. Alternatively, where indicated, a batch elution with $2.0 \mathrm{M} \mathrm{NaCl}$ was performed following the heparin wash. Proteins were precipitated from column fractions with trichloroacetic acid and analyzed by SDS-PAGE and immunoblotting as described.

\section{Acknowledgments}

We are grateful to Dawn Sailer and Terry Nakagawa for excellent technical assistance, to Margaret Schwab for help with the heparin experiments, and to Drs. Maurice Swanson and Raymond Bandziulis for helpful discussions and comments on the manuscript. We thank Drs. Barbara Merrill and Kenneth Williams for kindly providing purified UP2. This work was supported by grants from the National Institutes of Health (GM-31888 and GM-37125). G.D. is an Established Investigator of the American Heart Association.

\section{References}

Adam, S.A., T.Y. Nakagawa, M.S. Swanson, T. Woodruff, and G. Dreyfuss. 1986. mRNA polyadenylate-binding protein: Gene isolation and sequencing and identification of a ribonucleoprotein consensus sequence. Mol. Cell. Biol. 6: 29322943.

Beyer, A.L., M.E. Christensen, B.W. Walker, and W.M. LeStourgeon. 1977. Identification and characterization of the packaging proteins of core 40S hnRNP particles. Cell 11: 127138.

Beyer, A.L., O.L. Miller, Jr., and S.L. McKnight. 1980. Ribonucleoprotein structure in nascent hnRNA is nonrandom and sequence-dependent. Cell 20: 75-84.

Choi, Y.D. and G. Dreyfuss. 1984a. Isolation of the heterogeneous nuclear ribonucleoprotein complex (hnRNP): A unique supramolecular assembly. Proc. Natl. Acad. Sci. 81: $7471-7475$.

- 1984b. Monoclonal antibody characterization of the C proteins of heterogeneous nuclear ribonucleoprotein complexes in vertebrate cells. J. Cell Biol. 99: 1997-2004.
Choi, Y.D., P.J. Grabowski, P.A. Sharp, and G. Dreyfuss. 1986. Heterogeneous nuclear ribonucleoproteins: Role in RNA splicing. Science 231: 1534-1539.

Chung, S.Y. and J. Wooley. 1986. Set of novel, conserved proteins fold premessenger RNA into ribonucleosomes. Proteins 1: 195-210.

Dreyfuss, G. 1986. Structure and function of nuclear and cytoplasmic ribonucleoprotein particles. Annu. Rev. Cell Biol. 2: 459-498.

Dreyfuss, G., S.A. Adam, and Y.D. Choi. 1984a. Physical change in cytoplasmic messenger ribonucleoproteins in cells treated with inhibitors of mRNA transcription. Mol. Cell. Biol. 4: 415-423.

Dreyfuss, G., Y.D. Choi, and S.A. Adam. 1984b. Characterization of hnRNA-protein complexes in vivo with monoclonal antibodies. Mol. Cell. Biol. 4: 1104-1114.

Economides, I.V. and T. Pederson. 1983. Structure of nuclear ribonucleoprotein: Heterogeneous nuclear RNA is complexed with a major sextet of proteins in vivo. Proc. Natl. Acad. Sci. 80: 1599-1602.

Foe, V.E., L.E. Wilkinson, and C.D. Laird. 1976. Comparative organization of active transcription units in Oncopeltus fasciatus. Cell 9: 131-146.

Frosch, M., I. Gorgen, G.J. Boulnois, K.N. Timmis, and D. Bitter-Suermann. 1985. NZB mouse system for production of monoclonal antibodies to weak bacterial antigens: Isolation of an IgG antibody to the polysaccharide capsules of Escherichia coli $\mathrm{Kl}$ and group B meningococci. Proc. Natl. Acad. Sci. 82: 1194-1198.

Herrick, G. and B. Alberts. 1976. Purification and physical characterization of nucleic acid helix-unwinding proteins from calf thymus. J. Biol. Chem. 251: 2124-2132.

Holcomb, E.R. and D.L. Friedman. 1984. Phosphorylation of the C-proteins of HeLa cell hnRNP particles. I. Biol. Chem. 259: $31-40$.

Jacob, M., G. Devilliers, J.P. Fuchs, H. Gallinaro, R. Gattoni, C. Judes, and J. Stevenin. 1981. In The cell nucleus led. H. Busch|, vol. 8, pp. 194-259. Academic Press, New York.

Karn, J., G. Vidali, L.C. Boffa, and V.G. Allfrey. 1977. Characterization of the non-histone nuclear proteins associated with rapidly labeled heterogeneous nuclear RNA. I. Biol. Chem. 252: 7307-7322.

Konarska, M.M. and P.A. Sharp. 1986. Electrophoretic separation of complexes involved in the splicing of precursors to mRNAs. Cell 46: 845-855.

Kumar, A. and T. Pederson. 1975. Comparison of proteins bound to heterogeneous nuclear RNA and messenger RNA in HeLa cells. J. Mol. Biol. 96: 353-365.

Lahiri, D.K. and J.O. Thomas. 1986. A cDNA clone of the hnRNP $C$ proteins and its homology with the singlestranded DNA binding protein UP2. Nucleic Acids Res. 14: 4077-4094

Laird, C.D., L.E. Wilkinson, V.E. Foe, and W.Y. Chooi. 1976. Analysis of chromatin-associated fiber arrays. Chromosoma 58: $169-192$.

Laskey, R.A. and A.D. Mills. 1975. Quantitative film detection of ${ }^{3} \mathrm{H}$ and ${ }^{14} \mathrm{C}$ in polyacrylamide gels by fluorography. Eur. $J$. Biochem. 56: 335-341.

Leser, G.P., J. Escara-Wilke, and T.E. Martin. 1984. Monoclonal antibodies to heterogeneous nuclear RNA-protein complexes. J. Biol. Chem. 259: 1827-1833.

LeStourgeon, W.M., L. Lothstein, B.W. Walker, and A.L. Beyer. 1981. The composition and general topology of RNA and protein in monomer $40 S$ ribonucleoprotein particles. In The cell nucleus (ed. H. Busch), vol. 9, pp. 49-87. Academic Press, New York. 
Lothstein, L., H.P. Arenstorf, J.C. Wooley, S.Y. Chung, B.W. Walker, and W.M. LeStourgeon. 1985. The general organization of protein and RNA in HeLa 40S ribonucleoprotein particles. J. Cell. Biol. 100: 1570-1581.

Martin, T.E., P. Billings, A. Levey, S. Ozarsian, I. Quinlan, H. Swift, and L. Urbas. 1974. Some properties of RNA-protein complexes from the nucleus of eukaryotic cells. Cold Spring Harbor Symp. Qúant. Biol. 42: 899-909.

Martin, T.E., P.B. Billings, J.M. Pullman, B.J. Stevens, and A.J. Kinniburgh. 1978. Substructures of nuclear ribonucleoprotein complexes. Cold Spring Harbor Symp. Quant. Biol. 42: 899-909.

Maundrell, K. and K. Scherrer. 1979. Characterization of premRNA-containing nuclear ribonucleoprotein particles from avian erythroblasts. Eur. J. Biochem. 99: 225-238.

Maxwell, I.H., F. Maxwell, and W.E. Hahn. 1977. Removal of RNase activity from DNase by affinity chromatography on agarose-coupled aminophenyl-phosphoryluridine-2' $\left(3^{\prime}\right)$ phosphate. Nucleic Acids Res. 4: 241-246.

Mayrand, S., B. Setyono, J.R. Greenberg, and T. Pederson. 1981. Structure of nuclear ribonucleoprotein: Identification of proteins in contact with $\operatorname{poly}(\mathrm{A})^{+}$heterogeneous nuclear RNA in living HeLa cells. J. Cell Biol. 90: 380-384.

McKnight, S.L. and O.L. Miller. 1976. Ultrastructural patterns of RNA synthesis during early embyogenesis of Drosophila melanogaster. Cell 8: 305-319.

Miller, O.L. and A.H. Bakken. 1972. Morphological studies of transcription. Karolinska Symp. Res. Methods Reprod. Endocrinol. 5: 155-167.

O'Farrell, P.Z., H.M. Goodman, and P.H. O'Farrell. 1977. High resolution two-dimensional electrophoresis of basic as well as acidic proteins. Cell 12: 1133-1142.

Osheim, Y.N., O.L. Miller, and A.L. Beyer. 1985. RNP particles at splice junction sequences on Drosophila chorion transcripts. Cell 43: 143-151.

Pandolfo, M., O. Valentini, G. Biamonti, P. Rossi, and S. Riva. 1987. Large-scale purification of hnRNP proteins from HeLa cells by affinity chromatography on ssDNA-cellulose. Eur. J. Biochem. 162: 213-220.

Pederson, T. 1974. Proteins associated with heterogeneous nuclear RNA in eukaryotic cells. J. Mol. Biol. 83: 163-183.

Riva, S., C. Morandi, P. Tsoulfas, M. Pandolfo, G. Biamonti, B. Merrill, K.R. Williams, G. Multhaup, K. Beyreuther, H. Werr, B. Henrich, and K.P. Schaefer. 1986. Mammalian single-stranded DNA binding protein UP I is derived from the hnRNP core protein Al. EMBO I. 5: 2267-2273.

Samarina, O.P., E.M. Lukanidin, J. Molman, and G.P. Georgiev. 1968. Structural organization of nuclear complexes containing DNA-like RNA. J. Mol. Biol. 33: 251-263.

Sierakowska, H., W. Szer, P.J. Furdon, and R. Kole. 1986. Antibodies to hnRNP core proteins inhibit in vitro splicing of human $\beta$-globin pre-mRNA. Nucleic Acids Res. 14: 5241 5254.

Steitz, J.A. and R. Kamen. 1981. Arrangement of 30S heterogeneous nuclear ribonucleoprotein on polyoma virus late nuclear transcripts. Mol. Cell. Biol. 1: 21-34.

Stevenin, J.H., R. Gallinaro-Matringe, R. Gattoni, and M. Jacob. 1977. Complexity of the structure of particles containing heterogeneous nuclear RNA as demonstrated by ribonuclease treatment. Eur. J. Biochem. 74: 589-602.

Swanson, M.S., T.Y. Nakagawa, K. LeVan, and G. Dreyfuss. 1987. Primary structure of human nuclear ribonucleoprotein particle $C$ proteins: Conservation of sequence and domain structures in heterogeneous nuclear RNA, mRNA and pre-rRNA-binding proteins. Mol. Cell. Biol. 7: 1731-1739.

Valentini, O., G. Biamonti, M. Pandolfo, C. Morandi, and S.
Riva. 1985. Mammalian single-stranded DNA binding proteins and heterogeneous nuclear RNA proteins have common antigenic determinants. Nucleic Acids Res. 13: $337-346$.

van Eekelen, C.A.G., E.C.M. Mariman, R.J. Reinders, and W. van Venrooij. 1981. Adenoviral hnRNA is associated with host proteins. Eur. J. Biochem. 119: 461-467.

van Eekelen, C.A.G. and W.J. van Venrooij. 1981. hnRNA and its attachment to a nuclear protein matrix. I. Cell. Biol. 88: $554-563$.

Walker, B.W., L. Lothstein, C.L. Baker, and W.M. LeStourgeon. 1980. The release of $40 S$ hnRNP particles by brief digestion of HeLa nuclei with micrococcal nuclease. Nucleic Acids Res. 8: 3639-3657.

Wilk, H.E., H. Werr, D. Friedrich, H.H. Kiltz, and K.P. Schaefer. 1985. The core proteins of $35 \mathrm{~S}$ hnRNP complexes: Characterization of nine different species. Eur. I. Biochem. 146: $71-81$. 


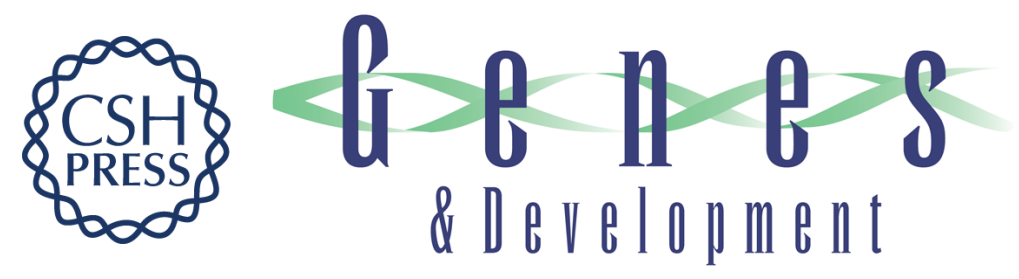

\section{Immunopurification of heterogeneous nuclear ribonucleoprotein particles reveals an assortment of RNA-binding proteins.}

S Piñol-Roma, Y D Choi, M J Matunis, et al.

Genes Dev. 1988, 2:

Access the most recent version at doi:10.1101/gad.2.2.215

$\begin{array}{ll}\text { References } & \text { This article cites } 45 \text { articles, } 18 \text { of which can be accessed free at: } \\ \text { http://genesdev.cshlp.org/content/2/2/215.full.html\#ref-list-1 }\end{array}$

License

Email Alerting Receive free email alerts when new articles cite this article - sign up in the box at the top Service right corner of the article or click here.

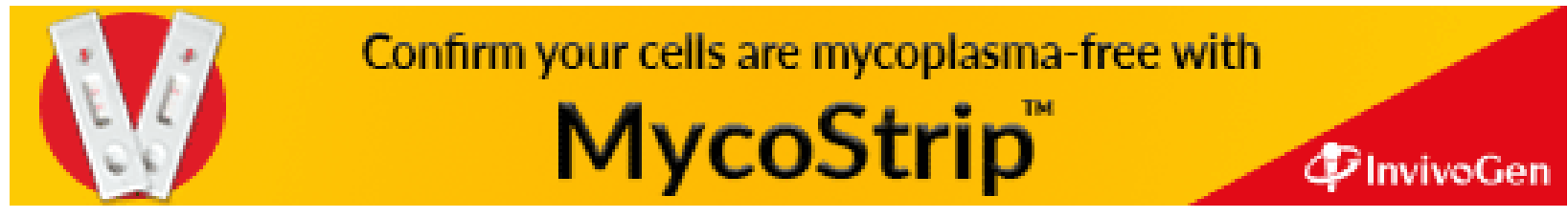

